\title{
Physical Education Teachers' Views about Character Education
}

\author{
Erkut Tutkun ${ }^{1}$, İlyas Görgüt ${ }^{2} \&$ İbrahim Erdemir ${ }^{3}$ \\ ${ }^{1}$ Sports Faculty, Uludag University, Bursa, Turkey \\ ${ }^{2}$ School of Physical Education and Sports, Dumlupinar University, Kutahya, Turkey \\ ${ }^{3}$ School of Physical Education and Sports, Balikesir University, Balikesir, Turkey \\ Correspondence: İbrahim Erdemir, School of Physical Educaiton and Sports, Balikesir University, Balikesir \\ Turkey. Tel: 90-053-2227-1930. E-mail: iboerdemir@gmail.com
}

Received: June 19, 2017

doi:10.5539/ies.v10n11p86
Accepted: July 20, $2017 \quad$ Online Published: October 28, 2017

URL: https://doi.org/10.5539/ies.v10n11p86

\begin{abstract}
The purpose of this study is to find out the views of teachers of physical education about how they define character education, whether they think national education curriculum and the curriculum of private schools are suitable for character education and whether they think character education can be applied in physical education lessons. Case report design was used in this study which was prepared with qualitative research method. The sample group of the study consists of 6 physical education teachers working in 3 secondary schools and 2 high schools of Kütahya city center which were determined with easily accessible case sampling method, which is one of the purposive sampling methods. Individual interviews which lasted for an average of 15-20 minutes were conducted with physical education teachers within the context of semi-structured interview technique. The participants were informed that the interviews would be voice recorded and later their expressions would be written down to avoid data loss and after necessary permissions were taken, the interviews were recorded. Descriptive and content analysis methods were used to analyze the expressions which were converted into text. The results of the analyses showed that physical education teachers defined character education as changes that occurred in individuals' behaviors first in the family, then at school and the education conducted to teach individuals socially accepted and correct behaviors. In addition, it was found that the teachers stated that the current curriculum of the country and also physical education curriculum were not suitable for character education; however, since it is a social lesson and since participants are continuously active and in communication, physical education lessons can be more effective than other lessons in terms of character development.
\end{abstract}

Keywords: physical education, teacher, character, education, view

\section{Introduction}

For centuries, human beings have experienced great changes and developments. In addition to bringing great advantages, the resulting cycle of change also brings together negative massive consequences, the effects of which can be felt in almost every area. Countries, thus, the human kind have been influenced by these negations the most because the changes occurring in the socio-cultural life of an individual bring along physical, mental and moral corruption. As a natural consequence of this, generations are influenced and the states' long-term plans receive blows. Thus, the goal of raising intelligent and healthy individuals and the idea that developing mankind will contribute to fighting lots of negations in society accelerate strategies and works which directly aim to improve or develop individuals' character. Thus, with these practices, we are faced with the concept of character education.

The movement of character education is expressed as reactions to spiritual void that occurred after social and scientific transformations caused by the 21st century (Hymowitz, 2003, cited from Mullins, 2011). It is a wide umbrella term used by educators in developing good values and characteristics in young people (Jones, Ryan, \& Bohlin, 1999). Benninga et al. (2006) define character education virtues of human relations such as respect, justice and tolerance; values of the self such as courage, self-discipline and ambition, or a combination of both. In addition, it is also viewed as an umbrella term which tells the efforts to teach citizenship values such as respect and responsibility, social and emotional learning, empathy and affection, tolerance and community service (Schwartz, Beatty, \& Dachnowicz, 2006). In its most general sense, it is the common name given to the 
efforts of helping the new generation to gain basic human values, to create sensitivity to values and to turn them into behaviors through direct or indirect programs in the curriculum (Ekşi \& Katılmış, 2011), it is the effort for individuals' being educated under the most difficult conditions (Agboola \& Tsai, 2012). According to Elias (2010), character education creates a safer learning environment, decreases the level of violence, discipline problems and cheating, and associates ethical and moral values with each other for a humane environment (Demirel et al., 2016). According to Faturrohman (2013), character education focuses on basic human character derived from universal moral values. It originates from religion and it is called the golden rule. According to psychologists, there are some character values such as loving the creator and his creations, responsibility, honesty, being respectful and kind, being compassionate and helpful, cooperation, trust, creativity, hard work, justice and leadership, being good and moderate, tolerance, peace, unity and love. The practice of character education in schools should be based on these basic character values. In the future, these educational practices should be turned into more and higher values in line with needs, conditions and school environment (Mislia et al., 2016).

Character education is a priority as important as children's academic achievement and it is based on children's ethical, social and emotional development beliefs (Phanthachack, 2012). A conscious effort is required for the realization of virtues. It expresses school virtues such as respect and responsibility and encourages them openly whenever possible. It is important to think and discuss; however, it is behavior that should be emphasized and accepted as the ultimate measure of character (Lickona, 1999). In addition, character education is the education movement that supports students' social, emotional and ethical development. It is a proactive effort, that is, an effort to influence the individual, to install the core, ethical and performance values of care, honesty, effort, justice, resolution, responsibility, self-respect and respect for others. Character education brings long-term moral, ethical and academic solutions to issues that cause interest in societies and schools and teaches children how best they can be and how to do the best job (Character Education Partnership, 2017). Schaeffer (1999) emphasizes that schools' oldest duty, which is a part of their mission, is to encourage and promote character education (Lewis \& Ponzio, 2016). Otten (2000) states that the responsibility in determining basic values to give in these educations and making students gain these values through experiences falls to schools. A common attitude should be shown about the characteristics to be taught and they should be presented in a whole learning environment such as sports center, canteen or cafeteria. In addition, individuals are asked to model these characteristics which are a part of the society (Demirel et al., 2016). Character education is beyond being a program prepared for the behaviors and achievement of children at school. It is also viewed as the installation of moral values by creating a safe atmosphere through solving special issues and problems of the society (Graff, 2012). Lake (2011) puts forward that increased violence and violent acts in schools revived the concept of good character. The most important partners for the solution of this negation are teachers, managers, other staff and parents (Temiz, 2016).

Teachers have the greatest influence on students' character following the parents (Arthur, 2011) because students spend a specific period of their day with their teachers and friends and take those around them, especially teachers, as role model. Thus, the first point to reach for character education is educational institutions and the teachers working there. Although there are limited studies for character education in our country, the values which are aimed to be given to students are presented among lesson units indirectly. In addition, this practice is mostly seen in theoretical lessons. However, such a situation is seen less in applied lessons such as physical education which provide social interaction and continuous communication that could be better for character education and the process is conducted with the individual efforts of teachers. Thus, the information obtained in the light of their experiences will make great contributions in developing educational strategies or program. Thus, when one wants to find out whether the curriculum especially the curriculum of physical education lesson is suitable for character development and whether it is possible to give character education in physical education lesson, the first place to refer to is teachers and their views on this. So the research is important in terms of determining the opinions of teachers who have a great influence on the students, educate the next generations and have a big role in the healthy progress of the nations in every area. In particular, the physical education course and the physical education teacher are very important in character education because of developing the individual as a whole. For this reason, study was conducted to find out the views of physical education teachers about character education. In addition, another purpose of this study is to attract the attention of education programmers and physical education teachers to the concept of character education in physical education.

\section{Method}

This is a qualitative research, the purpose of which is to examine the views of physical education teachers about the concept of character education, about the suitability of curriculums to character education and about whether 
character education can be conducted through physical education. Qualitative research is defined as a type or research which follows a qualitative process to present the perceptions and cases, the data of which are collected through qualitative data collection methods such as observation, interview and document analysis, in a realistic and integrative environment and it has designs such as creating hypothesis, case study and act research (Yildırım \& Şimşek, 2013). Phenomenology research design was used in the study. Phenomenology is a research method which has specific characteristics of a philosophical content. This method includes the analysis of the individual universe, that is, individual experiences, individuals' perceptions and the meanings they allocate to these (Baş and Akturan, 2013).

\subsection{Study Group}

6 physical education teachers working in secondary school $(n=3)$ and high school $(n=3)$. Three of them are female (age $=31,34$ and 37$)$ and three of them are male $(\mathrm{age}=33,39$ and 42$)$ participants. It can be seen that their years of service differed between 3-19 years (female $=3,4$ and 14 years, male $=4,15$ and 19 years). Easily accessible sampling method, which is one of the purposive sampling methods, was used to choose the sample. This method saves speed and practicality since it chooses the situations which are close and accessible to the researcher (Yıldırım \& Şimşek, 2013).

\subsection{Data Collection Process}

Semi-structured interview technique was used to evaluate physical education teachers' views about character education. While preparing the questions for teachers who participated in our study, existing information in literature was compiled and a question bank was created. For content and structure validity of the questions, the questions were checked by experts and the necessary edits were made and it was decided to ask 4 questions. The teachers were first informed that the interviews would be voice recorded, these records would be kept by the researcher and other people would not be able to reach them and later on, these recordings would be transcribed and analyzed. After a comfortable environment was provided and necessary permissions were taken, the interviews were made face to face with a voice recorder. The interviews lasted for an average of 20 minutes. The questions in the study are below:

Question 1: Can you describe character education in short? Why do we need it as a society?

Question 2: How suitable is our curriculum for character education? Which lessons can be effective in character education?

Question 3: What kind of practices are there in the curriculum of physical education and sports lesson for character education?

Question 4: What are your thoughts about the applicability of character education through physical education?

\subsection{Data Analysis}

The interviews recorded by the researcher were computerized. The teachers were coded as T1, T2, T3, T4, T5 and T6 through Maxqda statistical program, the texts were analyzed descriptively and in terms of content. Content analysis was included to create categories in line with the teachers' views about character education and descriptions and direct quotations were included for reliability.

\section{Results}

Under this section, the answers obtained from questions asked to teachers are given in categorical charts obtained from the statistics program. The participants were asked 4 questions with semi-structured interview and descriptive and content analysis were used. The question "Can you describe character education in short? Why do we need it as a society?" was asked to the physical education teachers who participated in the study. The teachers first defined character and then stated their views about character education. Lastly, they expressed their ideas about why they thought the society needed character education. The definition of character formed by the answers of the teachers is given in Figure 1, while views about character education are given in Figure 2. 


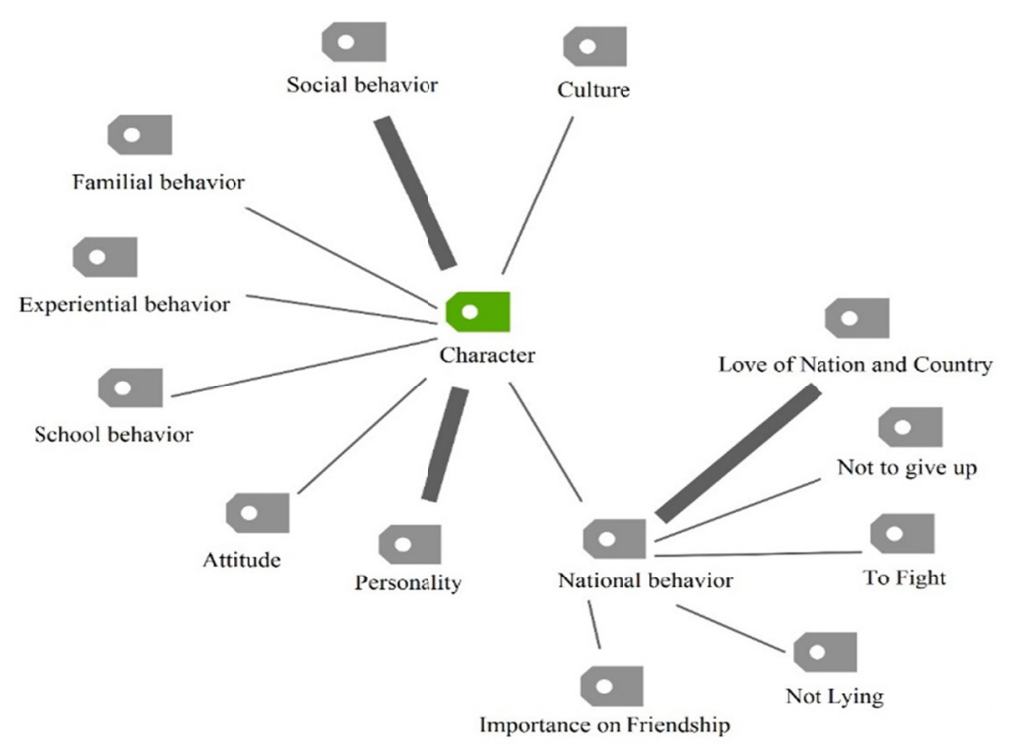

Figure 1. Expressions about the concept of character

Mostly, teachers defined the concept of character as a student's specific character which is mostly shaped within family and created as a result of experiences in society and which consists of the student's behavior at school and most importantly, natural and spiritual values. The following are some of the answers given by teachers:

T1: They are the behaviors shown by students in their environment, life and school. However, since family is in the core of these, they are behaviors which form under the family.

T2: In general, character is students'general attitudes, behaviors, actions and ways of behavior in society, their basic characteristics that differentiate them from others. Character is a nation's attitude, behaviors and one of the basic stages that shows at what stage a nation can be in the future. Our country has some specific characteristics: not to give up, to fight, not to lie, to consider friendship important and to protect the country and the race.

T4: There are some rules for human beings to continue to live or to be accepted within a society. People learn these rules first in the family, then at school and then in immediate environment and adapt to these slowly. The important thing here is family...People adapt to unwritten rules such as how they have to act in the family, with friends, within society or at school. 


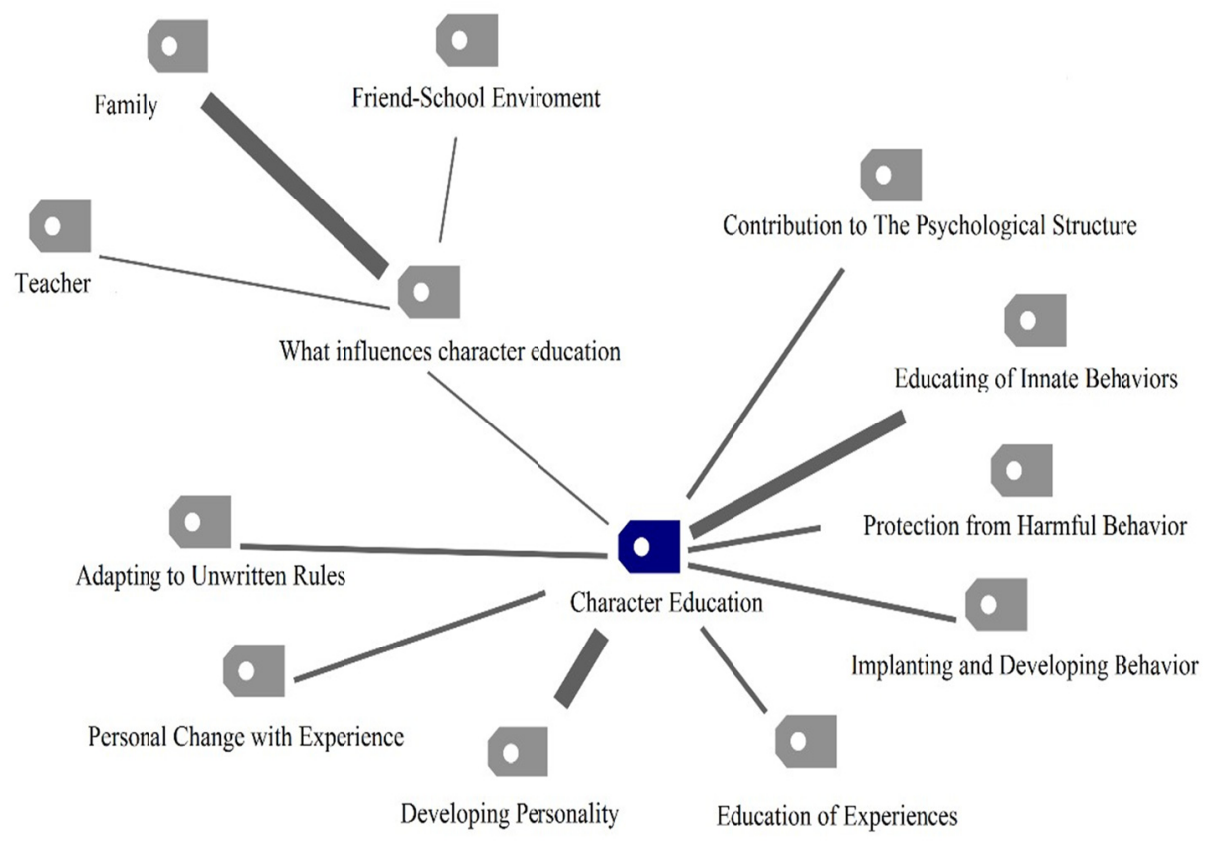

Figure 2. Expressions about the concept of character development

Teachers express character education as educational activities conducted with the aim of shaping individual's innate behaviors, making the individual adapt to unwritten rules, developing or changing character; in other words, educating experiences, protecting from harmful habits and supporting psychological structure. In addition, they state that first family, and then friends and school are effective on character education. Some answers of teachers about this definition are given below.

T3: Problems are beginning to arise day by day during the formation of children's characters such as parents' conflict, conflict in school and conflict among friends. All of these can be solved through education. Not only education, but also character education is very important. Showing the right behaviors, being the right person, educating for these and telling these are very important for the society.

T5: It is the education that starts from children's families. Later, we try to put it on the right track through instruction........... Character education is the behavior a child shows at school such as being respectful, being honest, not lying. In short, I can say that it is the moral education taken from the family. It is in the responsibility of the family, since it occurs first in the family.

T6: It is the development of an individual's character. It is contributing to an individual's psychological and mental development. In terms of education, the more we develop education, the more we support an individual's character development. 


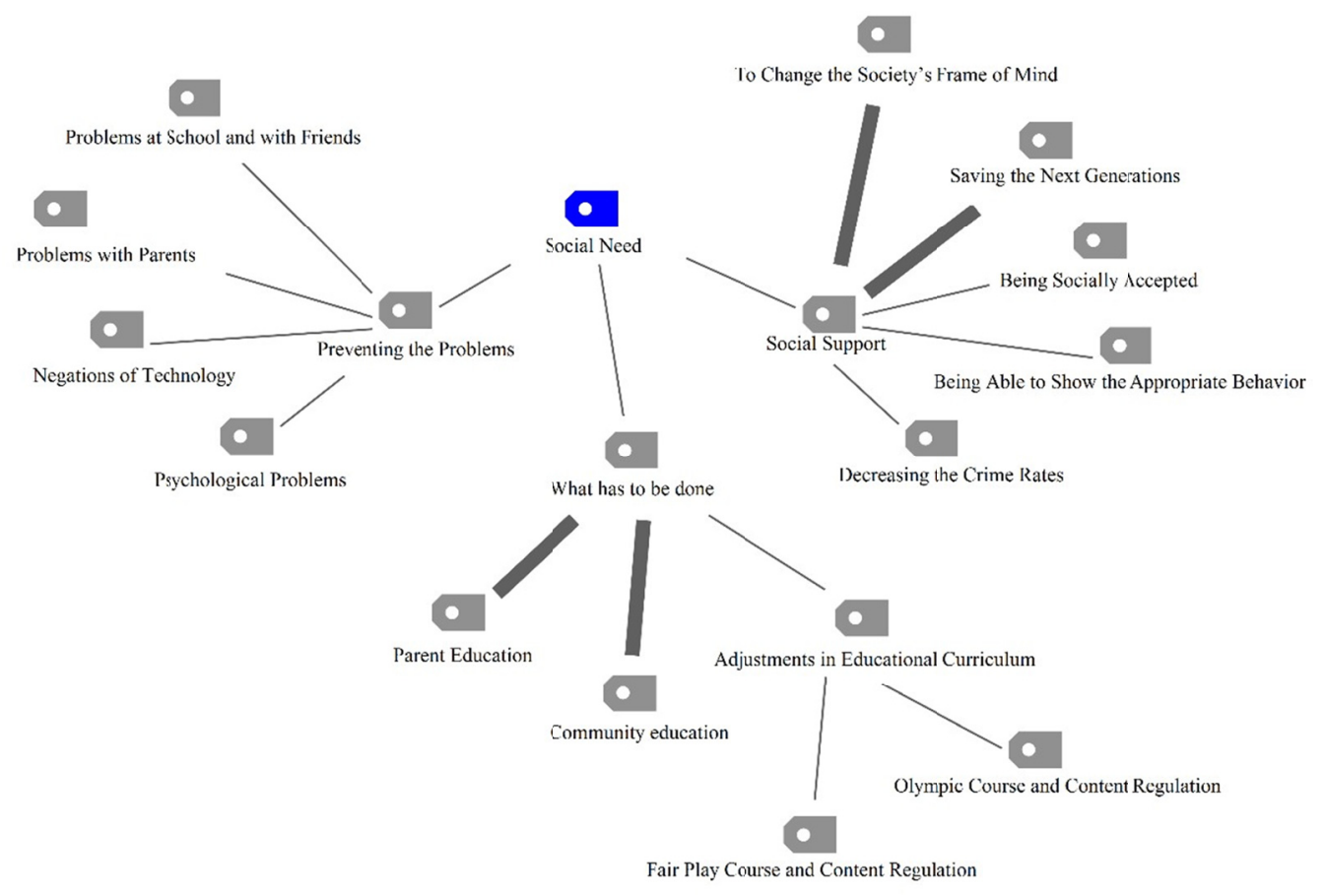

Figure 3. Expressions about social need for character education

According to teachers, character education is necessary to prevent problems and to support the society. The society needs character education to prevent especially the conflicts within the family, the problems among friends and at school, psychological problems and character problems that occur with technology. Some of the views of teachers about why the society needs character education are given below.

T2: One of the reasons why today there are suicides and increases in crime rates is the fact that we cannot give enough character education to our students and we cannot prevent the harmful habits caused by technology.

T3: We certainly need character education as a society because we don't know what character and character is, its consequences and positive attainments as a society. The society, notably the parents, should be educated about this.

T5: We need character education as a society. Character education is an essential subject for a good future. I believe that school counselors can give this education easily. Right now, we are talking without having received an education, with our knowledge back from formation lessons. After receiving this education, maybe we can make hereditary characteristics better. Thus, I believe that character education is necessary to raise generations that are loyal to the country and nation.

T6: When we give character education, we can change the society's structure of thinking. The better we can give this education which starts in the family and continues with the teacher at school, the more positive reflections it will have. It will enable bringing different perspectives to things in individuals.

The physical education teachers who participated in the study were asked the question "How suitable is our curriculum for character education? Which lessons can be effective in character education?". After the teachers stated their views about whether the curriculum in our country is suitable for character education, they stated their views about which lessons can be effective in character education. The data obtained from the teachers were given in Figure 4 


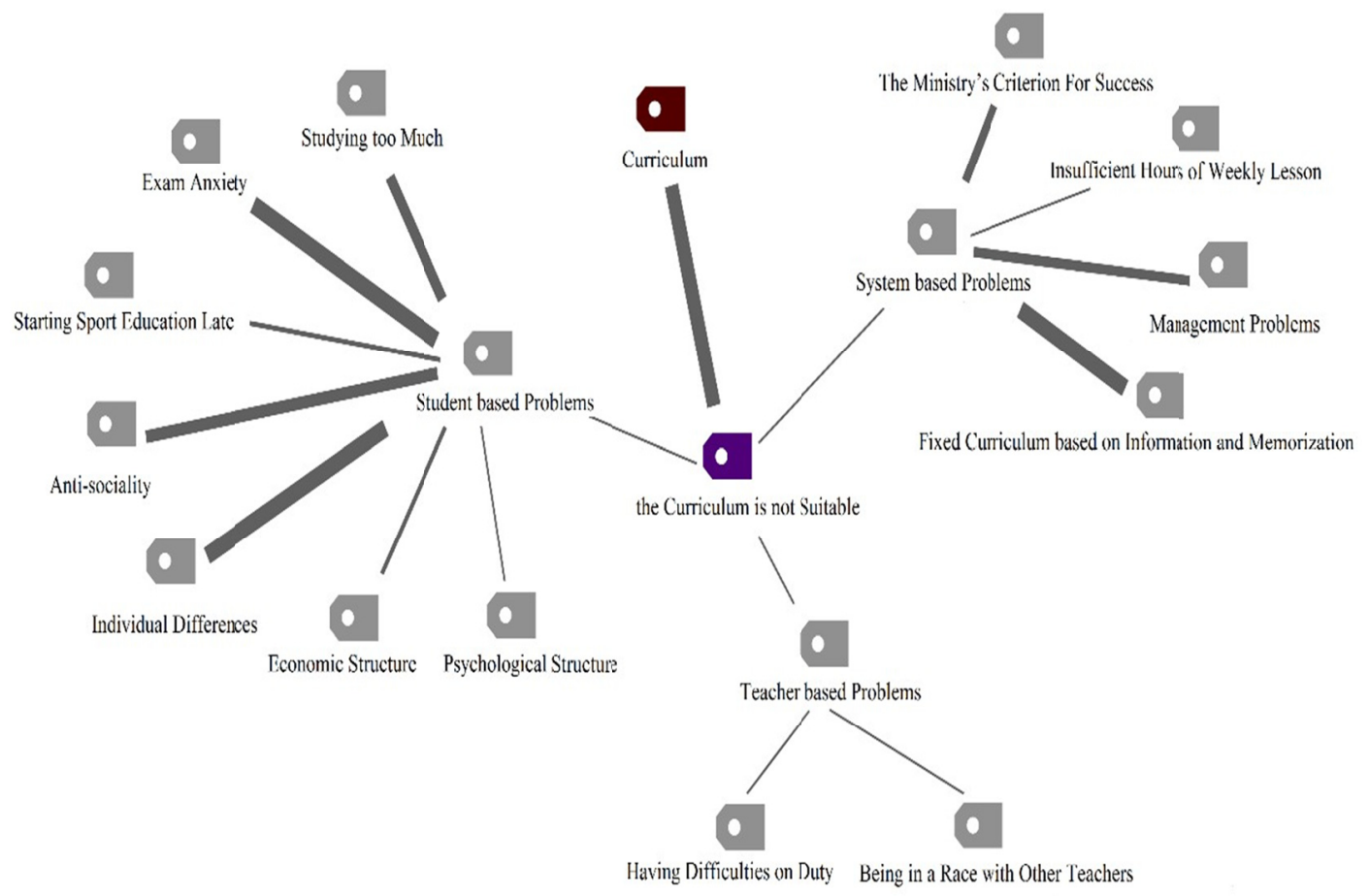

Figure 4. Expressions about the suitability of curriculum to character education

According to the teachers who participated in the study, the curriculum is not suitable for character education. It was expressed that it was not possible to give character education due to some problems in the existing curriculum. Some of the views of teachers about this situation are given below.

T1: I think our curriculum is not suitable for character education. In general, there are fixed expressions prepared by Ministry of National Education and Board of Education and Discipline and we try to apply these. However, just as every individual is different, students are also different.

T2: Unfortunately, since the loneliness wish of students come to the forefront recently with personal characteristics, individualization and the development of technology in society, sometimes students can get away at this point and can stay alone at the point of characterization....... Our curriculum or unfortunately our type of management cannot create enough pressure for children's education. At this point, we cannot take part in the primary position. The environment, or the technology, or media is more to the forefront, while the teacher is in the background.

T3: It certainly is. The curriculum is based completely on knowledge and memorization, exams are on the forefront, not many education models are taken into consideration to develop children's characters, even if they are taken into consideration, unfortunately there are some shortcomings at the point of practice. In my opinion, the development of the child's character should be given importance to; however, the current system prevents children from socializing. Since we have an education system which is based on exam system that leads them to study all the time, children spend their time between courses, private schools and private lessons.

T4: In terms of primary school, character education is given start from grade 1. However, it stays in the background later due to exam anxiety, the racing of teachers, and the fact that the Ministry bases success only on exam results and makes assessments thus. I believe that we will be much more successful if the process about having a good and established character and the process of what should be done about this was more on the forefront and the academic part was more on the background.

The teachers were asked about their opinions on which lessons they thought could be effective in character education. 


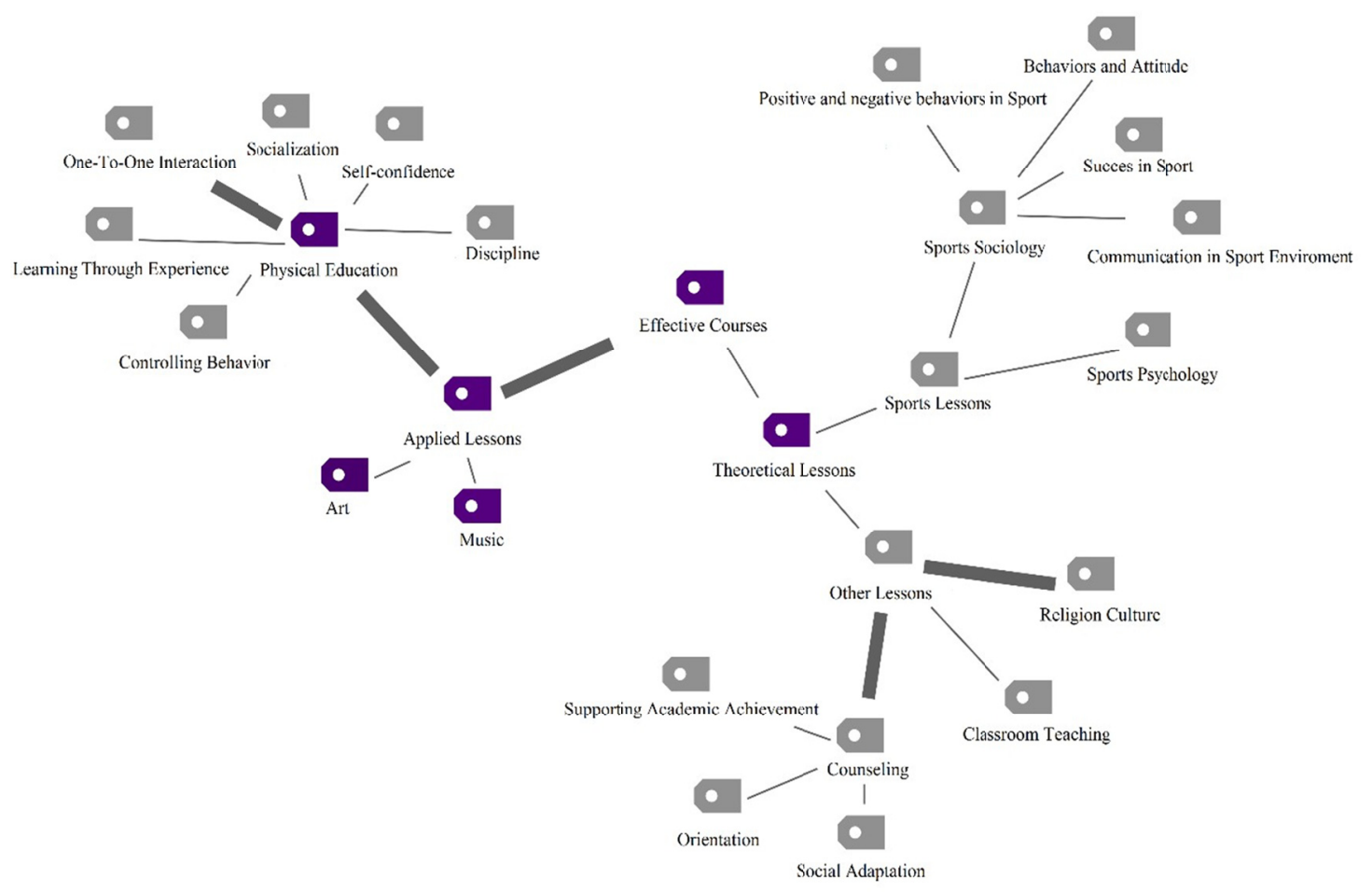

Figure 5. Expressions about which lessons can be effective in character education

Physical education teachers emphasized that in character education, mostly lessons with social content in which there is too much interaction and communication such as physical education, music and art, are effective, while theoretical lessons are not effective since they require academic success and being attached to the curriculum. However, counseling, primary teaching and the lessons of religious culture were also stated as lessons that affected character education to a certain extent. Some of the views of teachers about this situation are given below.

T1: I am not saying this because it is my branch, but physical education is certainly effective in character education. Other lessons will be learned by students more or less; however, they will affect socializing as much as the lessons of art, music or physical education.

T2: My first priority is counseling lessons because the subjects of counseling lesson are basic subjects such as which positions a child can get to in the future, which points he/she can reach in his relations with the environment, how he/she can manage supervision and social adaptation, how he/she can be successful in class, how failures can be solved, etc ....At this point, the lesson of sport psychology in sports high schools is very important. It has very big influences on people's behaviors, attitudes, acts, how they can be successful in sport, a great number of positive-negative acts that can occur with the excitement during sport and the associations with the environment outside of sport. Sport sociology is another lesson effective on character education. Even if character education is given within other lessons, this does not seem possible due to both number of lessons and the curriculum.

T3: ...........First of all, the lessons of physical education and sport, music and art are important....through experiences, children in this lesson learn about proper behavior, proper character and the child's character begins to form.... In physical education lesson, the child's character comes to the forefront. A student learns this first-hand. Another lesson that can contribute to character education is the lesson of religious culture. In these lessons, since teacher-student have a closer face-to-face interaction, students consider teachers as close to them and they can be reached easier.

Teachers of physical education were asked the question "What kind of practices are there in the curriculum of physical education and sports lesson for character education?". The teachers expressed their opinions about whether there were practices in the curriculum of physical education and sports lesson for character education. The data obtained from the teachers are given in Figure 6. 


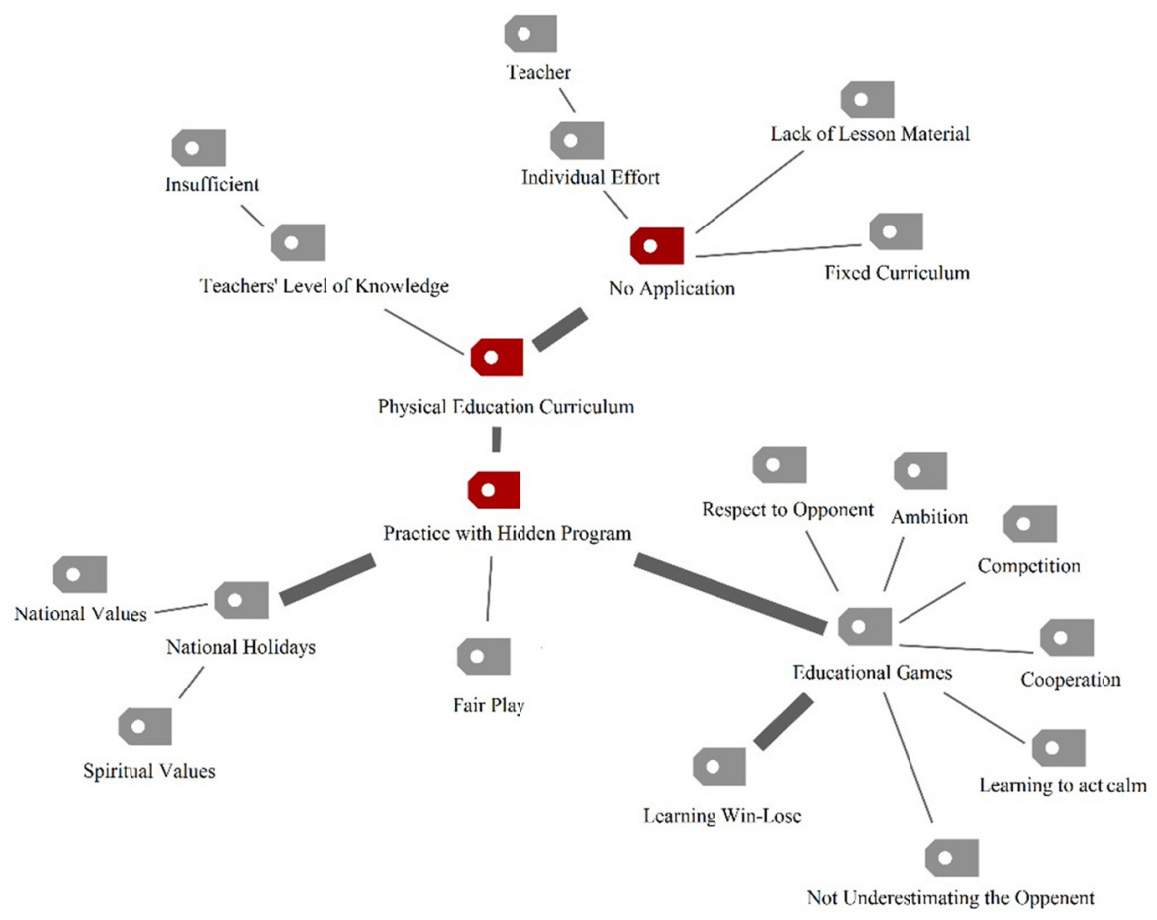

Figure 6. Expressions about the suitability of physical education curriculum to character education

The teachers of physical education in the study stated that there were no practices directly related with character education in the curriculum of physical education lesson, and that teachers tried to teach these indirectly through teachers' individual efforts with activities in lessons such as national holidays, fair play and educational games. The participants think that the reason why there are no practices is due to teachers' level of knowledge, insufficient materials and fixed curriculum. Some of the answers of teachers are as follows:

T1: There is no practice for character education, we take fixed programs and ready curriculum from the internet and use these. We prepare programs for your children with the materials that we have. We did not place any practices for character education.

T2: In terms of the curriculum of physical education, there is no direct section for character education; however, there are specific activities on May 19 youth and sports day, October 29 Week of Republic or April 23 national sovereignty days, and there are parts in these activities such as what happened in those days, the effects of these on our day and what we have to think and do at this point. However, these activities can stay only as a show-off and they are only shortly mentioned in the programs.

T3: When we look at the curriculum, while there are no practices on the basis of lessons, attainments have been added in some lessons recently based on students'character and behaviors.

T4: In physical education lessons, subjects such as respecting friends, winning and accepting losing are taught with especially educational games. We do not have separate sections or attainments directly related with character education; however, these are given within activities.

T5: When I think about the curriculum, what directly hits me is the fair play subject...However, there is no physical education curriculum stating that students can develop character or advance character if they do that sport or do that practice.

T6: While teaching branches, we teach games to teach children not to be selfish and to have a team spirit and here the child learns to be a team and to cooperate. In short, while there are no direct parts about character education, character education is given through some indirect element within practices.

Teachers of physical education were asked the question "What are your thoughts about the applicability of character education through physical education?". The teachers stated their thoughts about the applicability of character education through physical education. The categories formed with the answers of the teachers are given in Figure 7. 


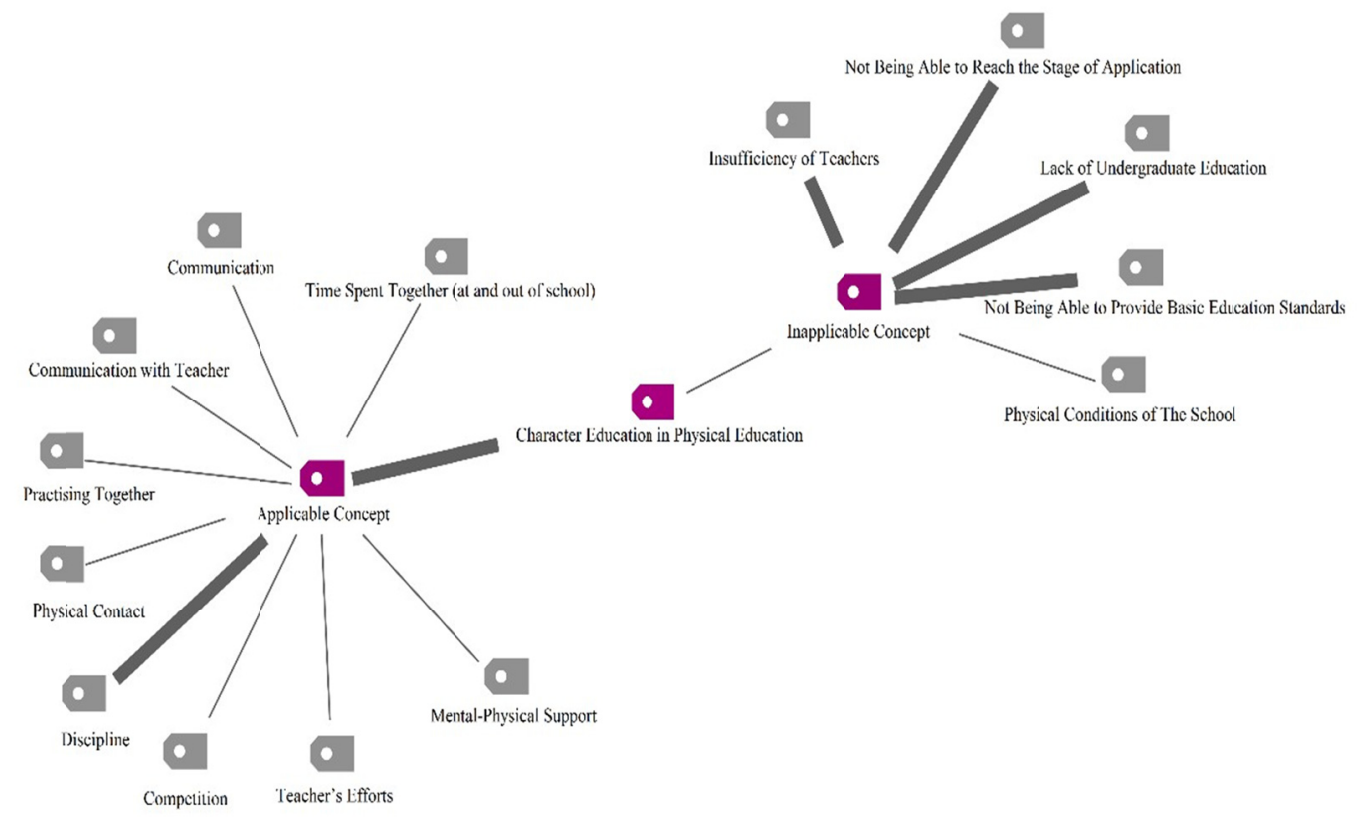

Figure 7. Expressions about the applicability of character education in physical education lesson

Teachers of physical education stated that the concept of character education is a concept applicable for physical education lessons due to its characteristics such as communication, applying together, physical contact and interaction, etc. However, it is also predicted that there may be some problems due to the insufficiency of teachers about character education, physical conditions, absence of undergraduate degree and some difficulties in application in our country. Some of the answers of teachers are below:

T2: Of course, it can be applied because there are obvious differences between physical education and other lessons. We think about physical education lesson as a lesson in which students can have physical contact with teachers, they can touch their teachers, communicate with them and use their gestures and mimics actively. When a student does the practice, since bodies can touch each other and since they can share the things they speak in case of feeling excited, I think that teachers and students are the closest in physical education lesson. Naturally, this causes physical education to come to the forefront in this field.

T3: It is difficult to apply under these circumstances; however, they should be applied and a great number of problems will be encountered during its application. First of all, there is the state of schools in our country and I don't believe that the teachers who will teach it are very informed about this. I don't think that they are trained for this. I believe that there are no lessons in university about character education and that they have some lacks about giving professional help....Since everything remains on paper in Turkey, it seems difficult that this will be put into practice. Applications can be made; however, it won't be possible to get any efficiency.... There is lack of facility and material in our country. However, it has to be done. Firstly, with pilot applications and plans, it can be possible to do it within the country.

T4: Physical education and character education are directly associated and it is the lesson in which character education can be applied in the best way. The contribution of physical education lesson to school discipline cannot be denied, especially while teaching the subjects in our curriculum, for example, we teach students not to despise others and to adjust the dose of their happiness and the feedback we get puts them in a discipline. However, in terms of character and character development, physical education lessons are important in turning negative character into positive character.

T5: I think that it can be applied; however, the sufficiency of teachers is also important here. Character education seems like the hidden part of education to me. As a teacher following the guidebook, I can say that although it is not taught directly, it is given indirectly.

T6: We can make positive contributions to character education with physical education lesson because I believe that physical education contributes to mental and physical development of the child and starting sports in young ages will have a positive effect on the character... Since the child is disciplined in physical 
education or a sports branch, his academic achievement also increases...Since the child learns discipline through sports, he reflects this to other lessons, too... That is, through physical education, character education practices have a positive reflection on education.

\section{Discussion}

In this study which was prepared to analyze the thoughts of physical education teachers on character education, teachers stated that character is shaped within family and the attitudes and behaviors of individuals within the family have an important role in giving a specific shape to the individual's character. The teachers also expressed that after the family, individuals developed their character through the interaction and experiences they had with other elements that form the society the individual is in. Narvaez and Nucci (2008) stated that people are shaped with just or unjust, noble or rude norms that they get from culture, tradition, society or their social environment. In addition, according to teachers, the biggest influence on a person's character comes from school and friends after family. The fact that they are in a continuous interaction with the friends and teachers they spend the majority of their time with and choosing role models for themselves shape their characters. Teachers also stated that when it comes to character, the first thing that comes to mind is national and spiritual values, these values form the individual's character, Turkish people place a great importance on these values and complying with these values is effective in being accepted by the society. According to Aydin (2010), character starts with the birth of an individual and advances within a changing and developing process that lasts for a lifetime. In the socialization and character of an individual who gets his first values from his family, the family has an important place. Thus, the communication, behaviors and attitudes of the family with the child are very important in terms of socialization and character of the child (Okmen et al., 2009).

Teachers of physical education assess character education as shaping the innate abilities of an individual, adapting the individuals to the rules created by the society which are generally unwritten, changing or developing some characteristics by making individuals experience things within suitable environments and making necessary directions, making individuals stay away from harmful habits that may break their psychological structure or the educational process conducted to make them get rid of these. They advocate that this process continues for a lifetime and that it is in a continuous change. In addition, they state that first the family, then friends and school and teacher are influential on character education. According to Creasy (2008), character education is a teacher's way of speaking, behaviors tolerated by the teacher, actions he encourages and the expectations he transmits. It is very important for a teacher not only to include character education in daily lessons but also to be a role model for students as a good individual. He should show patience and courtesy to children and show them that they should not do anything that they wouldn't like others do to them. However, in a study by Gündoğdu (2010), it was concluded that although teachers gave very much importance to subjects about character education during their lessons, these attitudes and behaviors were not reflected on the students and they were in moderate levels (Gündoğdu, 2010). Skinner (2013) stated in his study that the teachers were silent about which character education was suitable or had to be applied for their classes (Skinner, 2013).

Berkowitz (2005) mentions parent cooperation as another important side of character education. According to Berkowitz, although school is in a central position in developing students' characters, in terms of moral, behavioral or academic development, the greatest influence on the development of students comes from families, especially individuals' own families.

Çengelci (2015) stated that the cooperation between school-family-society is one of the vital components of character education; character education should be included in all school programs and should be supported with extracurricular activities. Webber (2003) stated that while a great number of educators believed that forming a character was the job of parents within the family, a great number of parents believed that character had to be taught at school within the frame of a specific curriculum and developmental psychology experts advocated that successful development of children required a consistent teaching and support model at home and at schools. Thus, in line with the information in our study and the literature, it is thought that an effective cooperation of the family and school for character and character education will support the individual positively and increase the efficiency of character education.

Teachers mention that with the development of technology, changes have occurred in society, and as a natural consequence of this, negations have occurred. Especially the fast changes in family relations increase the conflict between children and parents and the intensity of these conflicts and serious problems occur within friends and character problems occur naturally. Çokdolu (2013) concluded that a positive change occurred in conflict and aggression states of students with character education program. Uysal (2008) concluded that a great majority of character education programs had a positive meaningful effect on students' behaviors and academic achievement. 
Üstünyer (2009) found that character education was an immediate need, families failed to give universal values to their children, and teachers also failed due to their intense workloads and low efficiencies. At this point, it is assumed that character education is a very big need in solving the problems that occur with the age of technology and creating social peace.

According to the teachers who participated in the study, our current curriculum is not suitable for character education because of students' individual characteristics, teachers' professional competence and working conditions, and some problems resulting from the strategies and plans of the Ministry of National Education. The fact that the Ministry takes the success in exams as a criterion forced students in a big race, students became stuck between school, courses and private lessons and they began not to have any time for themselves. In addition to all these, negative influences of technology also created anti-social individuals whose only pursuit is to study at their desks. Besides, due to their insufficiencies about character education or due to the fact that parents don't want teachers to intervene to their children caused teachers to retreat to a more passive position. As a result of the fact that school managers cannot provide a suitable environment and condition, teachers do not see character education as an applicable concept with the existing curriculum. School managers are the primary determinant and responsible person for the application of character education and creating a more ethical climate or school culture within the school (Ereş, 2015). However, unlike the teachers who participated in the study, Yıldırım (2007) conducted a wide study across the country in order to design a character education program model proposal and to design its applicability and the participants of the study found the principles, structuring, functioning and sample activities of the related educational model as highly applicable.

When the lessons that can be effective in character education were assessed in our study, it was found that almost all of the teachers thought that practical and social lessons such as physical education, music and art could be more effective, especially physical education lessons which contained one-to-one contact and communication, required spontaneous and fast decision making and disciplined individuals could be more useful with this education. They emphasized that theoretical lessons were not effective since they required being strictly adhered to the curriculum; however, counseling, classroom teaching and religious culture lessons influenced character education to a certain extent. Making the curriculum more suitable for character education and solving the problems so that the lessons mentioned by teachers can be used effectively in character education makes the possibility of increasing the efficiency of character education in school stronger.

Teachers of physical education who participated in the study stated that there were no practices directly aiming character education within the physical education curriculum and further emphasized that the teacher had to do something through his personal efforts. Teachers aim to teach students some values within the context of the activities of national holidays (October 29 republic day, April 23 national sovereignty and children's day, etc.) and try to support their characters. In addition, by means of some activities shown in fair play and the lesson of educational games, character education is taught indirectly. Çubukçu (2012) defines hidden curriculum as the attitudes and behaviors of teachers and administrators, their attitudes to students, cooperative and competitive aspect of education, school environment and the learning environment it creates, the teaching process being inquisitive or based on rote-learning, in short, the attitudes reflected on students at school and the behaviors students show as a result of their interactions. Thus, as a result of a study on the association between school atmosphere and character education program, Thompson (2010) advocated that students should be given a direct character education so that they can create a positive school environment and maintain this. However, the participants stated that some problems such as teachers' level of knowledge, lack of material and fixed curriculum can be effective in the absence of character education practices. Although there is no practice in physical education curriculum on character education, teachers stated that because of its characteristics such as communication, cooperation, physical contact, discipline and interaction, physical education lessons are applicable for character education. Teachers also predict that some problems such as teachers' insufficiency about the concept, physical conditions, lack of undergraduate education and difficulties experienced in our country can create problems.

As a conclusion, when physical education teachers' opinions about character education were examined, it can be seen that level of knowledge about the concept of character education is low and there is not any differences between experienced and non-experienced teachers. They have almost the same ideas about the character education. And according to the teachers, our national education curriculum is not suitable for character education due to problems experienced in our country in the field of education. In addition, it is thought that an anti-social youth is raised since students experience exam anxiety because they are considered as successful based on their grades, and due to psychological problems triggered by technological negations, and students experience problems in their character since they cannot focus on their personal cares. When the curriculum is 
analyzed on the basis of lessons, since there are no character education practices in physical education lesson, it is assumed that teachers try to make the students gain some characteristics through some activities within the lesson.

\section{Suggestions}

Some suggestions are presented below in line with the findings of the research which was conducted to find out physical education teachers' views about character education.

- There should be theoretical and practical lessons in undergraduate programs of pre-service teachers about character education.

- Training programs should be organized to increase physical education teachers' levels of knowledge about character education.

- In the National Education program, there should be sections directly related with character education.

- Planning should be made for character education and strategies should be developed.

- A unit should be formed within the Ministry of Sport for character education and the country's sport policy should be directed accordingly.

- Weekly hours of social lessons (physical education, art, music) and their weights within the curriculum should be increased.

- Within the content of the physical education lesson, there should be sections and activity examples related with character education.

- Studies should be conducted to resolve exam anxiety and course load.

- Students' opportunities to participate in social activities should be developed and the number of extracurricular activities should be increased.

- $\quad$ Parent training programs should be organized to make character education more effective.

- Suitable conditions should be created at schools for character education and everyone related should get in-service training.

- The efficiency and functions of the counseling course should be increased.

\section{References}

Agboola, A., \& Tsai, K. C. (2012). Bring Character Education into Classroom. European Journal of Educational Research, 1(2), 163-170. https://doi.org/10.12973/eu-jer.1.2.163

Arthur, J. (2011). Personal character and tomorrow's citizens: Student expectations of their teachers. International Journal of Educational Research, 50, 184-189. https://doi.org/10.1016/j.ijer.2011.07.001

Aydın, M. Z. (2010). Ailede ahlak eğitimi. İstanbul: Timaş Yayınları

Baş, T. \& Akturan, U. (2013). Nitel araştırma yöntemleri Nvivo ile nitel veri analizi. Ankara: Seçkin Yayıncılık.

Benninga, J., Berkowitz, M., Kuehn, P., \& Smith, K. (2006). Character and academics: What good schools do. Phi Delta Kappan, 57(6), 448-52. https://doi.org/10.1177/003172170608700610

Berkowitz, M. (2005). Character education parents as partners. Educational Leadership, 63(1), 64-69

Çengelci, T. (2015). Ergenler için Karakter Eğitimi: Bir Araştırma Merkezine İlişkin Durum Çalışması. Eğitim ve Bilim, 40(179).

Character Education Partnership. (2017). 11 Principles of Effective Character Education. Retrieved from $\mathrm{http}: / /$ www.character.org/uploads/PDFs/Misc_/FAQs.pdf

Çokdolu, N. (2013). Karakter Eğitimi Programının İlköğretim 2. Kademe Öğrencilerinin Çatışma Çözme ve Saldirganlık Düzeylerine Etkisi. Yüksek Lisans Tezi, Necmettin Erbakan Üniversitesi, Eğitim Bilimleri Enstitüsü, Konya

Creasy, K. L. (2008). Is There a Place for Character Education? Retrieved from http://files.eric.ed.gov/fulltext/ED501652.pdf

Çubukçu, Z. (2012). İlköğretim öğrencilerinin karakter eğitimi sürecinde örtük programın etkisi. Kuram ve Uygulama Eğitim Bilimleri, 12(2), 1513-1534.

Demirel, M., Ozmat, D., \& Elgun, I. O. (2016). Primary school teachers' perceptions about character education. 
Educational Research and Reviews, 11(17), 1622-1633.

Ekşi, H., \& Katılmış, A. (2011). Karakter Eğitimi El Kitabı. Ankara: Nobel.

Ereş, F. (2015). Vatandaşlık eğitimi ve karakter eğitimi politikalarının değerlendirilmesine yönelik nitel bir çalışma. Mehmet Akif Ersoy Üniversitesi Eğitim Fakültesi Dergisi, 1(36), 120-136.

Gündoğdu, F. B. (2010). Ortä̈ğretim Kurumlarında Karakter Eğitimi Sorunu (Kayseri İli Örneği). Yüksek Lisans Tezi, Erciyes Üniversitesi, Sosyal Bilimler Enstitüsü, Kayseri.

Jones, E. N., Ryan, K., \& Bohlin, K. (1999). Character Education \& Teacher Education: How are Prospective Teachers Being Prepared to Foster Good Character in Students? Action in Teacher Education, 20(4), 11-28. https://doi.org/10.1080/01626620.1999.10462931

Lewis, M. \& Ponzio, V. (2016). Character education as the prımary purpose of schoolıng for the future. Jurnal Ilmiah Peuradeun, 4(2), 137-146.

Lickona, T. (1999). Character education: Seven crucial issues. Action in Teacher Education, 20(4), 77-84. https://doi.org/10.1080/01626620.1999.10462937

Mislia, M., Mahmud, A., \& Manda, D. (2016). The Implementation of Character Education through Scout Activities. International Education Studies, 9(6), 130. https://doi.org/10.5539/ies.v9n6p130

Mullins, J. L. (2011). Character education and 4-H youth development (Master thesis). Dean of the Graduate School of the University of Kentucky, USA.

Narvaez, D., \& Nucci, L. P. (Eds.). (2008). Handbook of moral and character education (pp. 310-327). Routledge.

Okmen, A. S., Erdemir, I., \& Tekin, H. A. (2009). The Comparison of Level of Socialization on Students Taking Elective Course, Physical Education, Art and Music Education. Balikesir University Journal of Social Sciences Institute, 12(21).

Phanthachack, L. (2012). Character education a qualitative review analysis and relevance of educational leader's perceptions and experiences with character development (Master thesis). Graduate Faculty of Fresno Pacific.

Schwartz, M., Beatty, A., \& Dachnowicz, E. (2006). Character education: Frill or foundation? Principal Leadership (High School Ed.), 7(4), 25-30

Skinner, G. S. (2013). First Grade Teacher Perceptions of a Character Education Program. Doctorate, Liberty University, USA.

Temiz, N. (2016). Example of Character Education Course Design in the Light of Experienced Centred Design for Higher Education. Journal of Education and Practice, 7(36), 144-155.

Thompson, L. (2010). Character Education and School Climate. Master, University of Minnesota Duluth, USA.

Üstünyer, F. (2009). Karakter Eğitimi ile İlgili Eğitimcilerin Görüşleri Üzerine Nitel Bir Araştırma. Yüksek Lisans Tezi, Yeditepe Üniversitesi, Sosyal Bilimler Enstitüsü, İstanbul.

Uysal, F. (2008). Karakter Ĕgitimi Programlarının Değerlendirilmesi. Yüksek Lisans Tezi, Yeditepe Üniversitesi, Sosyal Bilimler Enstitüsü İstanbul.

Webber, J. A. (2003). Failure to hold: The politics of school violence. Rowman \& Littlefield.

Yıldırım, A., \& Şimşek, H. (2013). Sosyal bilimlerde nitel araştırma yöntemleri. (9. Genişletilmiş Baskı) Ankara.

Yıldırım, G. (2007). Illköğretim Düzeyinde Bir Karakter Eğitimi Programı Model Önerisi ve Uygulanabilirliği. Doktora Tezi, Ankara Üniversitesi, Eğitim Bilimleri Enstiüsü, Ankara.

\section{Copyrights}

Copyright for this article is retained by the author(s), with first publication rights granted to the journal.

This is an open-access article distributed under the terms and conditions of the Creative Commons Attribution license (http://creativecommons.org/licenses/by/4.0/). 